\title{
Home range use of free-ranging cheetah on farm and conservation land in Botswana
}

\author{
AnnMarie Houser ${ }^{1,2, *}$, Michael J. Somers ${ }^{2,3}$ \& Lorraine K. Boast ${ }^{1}$ \\ ${ }^{1}$ Cheetah Conservation Botswana, Private Bag 0457, Gaborone, Botswana \\ ${ }^{2}$ Centre for Wildlife Management, University of Pretoria, Pretoria, 0002 South Africa \\ ${ }^{3}$ DST-NRF Centre of Excellence for Invasion Biology, University of Pretoria, Pretoria, 0002 South Africa \\ Received 4 June 2008. Accepted 23 October 2008
}

\begin{abstract}
Cheetah (Acinonyx jubatus) movements should be considered when developing management strategies for long-term survival and coexistence with humans. Although work has been done in Namibia, South Africa and Tanzania little data on the home range and territory size of cheetah in Botswana has been published. This study aimed to estimate male and female home range sizes and daily movement on farmland and a game reserve in Botswana. Cheetahs were monitored from October 2003 to April 2007. The cheetah were fitted with cell/GPS or VHF collars and released back into their home range. Single male home ranges were $494 \mathrm{~km}^{2}$ and $663 \mathrm{~km}^{2}$ and a coalition of two males had a home range of $849 \mathrm{~km}^{2}$ (fixed kernel method). The females' home ranges were $241 \mathrm{~km}^{2}$ and $306 \mathrm{~km}^{2}$ (fixed kernel method). Females travelled a mean distance of $2.16 \pm 0.07 \mathrm{~km} /$ day (range; 0-20 km/day) compared to $6.13 \pm 0.30 \mathrm{~km} /$ day (range; $0-39 \mathrm{~km} /$ day) in males. Female maximum daily travel increased from $4.17 \mathrm{~km} /$ day when cubs where in the den to $8.16 \mathrm{~km} /$ day when cubs had left the den.

Key words: Acinonyx jubatus, core area, distance travelled, females with cubs, home ranges, male territories, movement.
\end{abstract}

\section{INTRODUCTION}

Like many large carnivores, the worldwide cheetah (Acinonyx jubatus) population has declined dramatically over the last century, from 100000 in 1900 to 12 000-15 000 in 1995 (Marker et al. 2003a). The species is currently listed as vulnerable by IUCN (IUCN 2007) and after Namibia, Botswana is believed to have the second largest free-ranging cheetah population in the world (Purchase et al. 2007). However, little is known about the dynamics of Botswana's cheetah.

Recent studies have shown cheetah to be more adaptable to vegetation and prey conditions than previously thought (Bissett \& Bernard 2007). They inhabit a wide range of habitats from open savanna to thick bush (Caro 1994; Gros \& Rejmánek 1999; Durant 2002; Broomhall et al. 2003), and their home range sizes and movements vary greatly with vegetation, prey density, sex, social grouping, and age of cubs (Caro 1994; Marker 2002; Broomhall et al.2003). Home range sizes in cheetah have shown large variation, with estimates from $11 \mathrm{~km}^{2}$ in males and $23 \mathrm{~km}^{2}$ in females in Matusadona National Park, Zimbabwe (Purchase

\footnotetext{
*To whom correspondence should be addressed.
}

E-mail: amhouser3@yahoo.com
\& du Toit 2000) to $833 \mathrm{~km}^{2}$ in females and $777 \mathrm{~km}^{2}$ in non-territorial males in the Serengeti (Caro 1994). These studies were conducted in conservation areas, where cheetah are protected from human persecution, but often subjected to high rates of intraguild competition and kleptoparastism from lion (Panthera leo) and spotted hyaena (Crocuta crocuta). Within Botswana and other southern African countries cheetah are largely found outside of these protected areas, often at higher densities in agricultural, rather than conservation areas (Winterbach 2001; Marker 2002). In these areas human persecution is the main cause of death in adult cheetah of breeding age (Marker et al. 2003b) and conflict with livestock farming is believed to be a major threat to the overall cheetah population in Botswana (Klein 2007). As such, it is important to study cheetah home range and movements within these farmlands to find insights, which may assist in reducing their conflict with humans. A mean annual home range of $1651 \mathrm{~km}^{2}$ was found in Namibian farmlands, significantly larger than recorded elsewhere (Marker et al. 2007). The reasons for this were unclear, in protected areas prey migrations, low rainfall and avoidance of predators are thought to increase 
home range size (Caro 1994; Stander et al. 1997, Durant 2000; Broomhall 2001; Marker et al. 2007) However, on farmland permanent water points ensure prey is sedentary and as aforementioned large predators are absent. Human disturbance and perturbation is known to effect species ecology and behaviour (Tuyttens \& MacDonald 2000), and Marker et al. (2007) believed this may be affecting cheetah home range size in Namibia. This paper describes movements and home range size of free-ranging cheetah on Botswana farmland, to determine if similar large home ranges exist.

\section{METHODS}

\section{Study area}

The study was conducted in Jwaneng in the Southern district of Botswana and in the Ghanzi district of Botswana, from October 2003 to April 2007. The Jwaneng study area, $\left(24^{\circ} 33^{\prime} 09.3^{\prime \prime} S\right.$, $24^{\circ} 43^{\prime} 38.0^{\prime \prime} \mathrm{E}$ ) primarily consisted of the Jwana Game Reserve $\left(180.31 \mathrm{~km}^{2}\right)$, which surrounds the Jwaneng Diamond Mine, and the surrounding cattle posts. The cheetahs moved freely in and out of the reserve through warthog (Phacochoerus africanus) holes onto the surrounding farmland. The temperatures range from below zero to over $40^{\circ} \mathrm{C}$; with an annual mean rainfall of $398 \mathrm{~mm}$ (Greenway 2001; Jwaneng Meteorology Department 2007). The dry season is between April and October, and the wet season is between November and March. The area is sandveld with the major species being Acacia mellifera, Acacia luedritzii and Boscia albitrunca (A. Houser, pers. obs.). Vegetation is primarily open semi-wooded savanna mixed with moderate to thick bush. The topography of the area is flat, in a sandy aerosols environment with no hills or high rises, rivers or lakes.

The Ghanzi District study area (Ghanzi town: $21^{\circ} 41^{\prime} 50.62^{\prime \prime} \mathrm{S} ; 21^{\circ} 39^{\prime} 6.15^{\prime \prime} \mathrm{E}$ ) is part of the Kalahari ecosystem. Two thirds of this district is set aside for wildlife conservation or management (District Land Use Planning Unit-DLUPU 1995) with surrounding areas being cattle and game farms. The vegetation ranges from bush to open tree savanna, with dominant bush species of Grewia and Acacia spp. and dominant tree species being Acacia erioloba and Boscia albitrunca (Bekker \& de Wit 1991), this area is considered hardveld with some sandveld sections, with Terminalia sericea and Lonchocarpus nelsii dominating (A. Houser, pers. obs.). The wet season is between October and April, with an annual rainfall of $400 \mathrm{~mm}$ (Thomas 2002). The topography is relatively flat with pans and valleys, dominated by Kalahari sandy arenosols (Thomas 2002). There are no rivers or lakes in these areas, only man-made water points or natural pans within the farms, Central Kalahari Game Reserve (CKGR) and Wildlife Management Areas (WMAs).

\section{Capture and telemetry}

Cheetahs were captured using double-ended box traps $(2 \mathrm{~m} \times 0.8 \mathrm{~m})$ with a central treadle plate. The traps were set using live bait or limited access methods using acacia cuttings to block access to waterholes, marking trees or along fence lines.

On capture, cheetah were transported in wooden squeeze boxes $(1.2 \mathrm{~m} \times 0.8 \mathrm{~m})$ to the field base where they were tranquilized by the project veterinarian using $30-40 \mu \mathrm{g} / \mathrm{kg}$ of medetomidine (Dormitor) and $1 \mathrm{mg} / \mathrm{kg}$ of tiletamine-zolazepam (Zoletil). A medical workup was conducted using methods adapted from Marker (2002). This included the fitting of a VHF radio or cell/GPS collar.

Six VHF radio collars and four cell/GPS collars were placed on 11 cheetahs in the Jwaneng and Ghanzi Districts of Botswana (one of the collars was refurbished and reused). In male coalitions, the collar was placed on one member of the coalition only. Telonics (Telonics, Arizona, USA) and Africa Wildlife Tracking (AWT) (Africa Wildlife Tracking CC, Pretoria, South Africa) VHF radio collars, weighing $C .100 \mathrm{~g}$, were monitored using the Telonics H-antenna, with Telonics TR-4 receivers (148-152 MHz) from vehicles daily, or by plane weekly when possible. The AWT cell phone collars weighing $450 \mathrm{~g}$, recorded GPS locations one to four times a day. Times were chosen considering likely rest and movement periods at different times of day. By choosing times of day when the cheetahs were moving, it would increase the chances of getting a satellite fix on their location. This would then increase our ability to accurately determine daily movement data. All cheetah were released directly back into their home range, with the exception of one male who was released $30 \mathrm{~km}$ from his range in order to find a suitable release site. If released outside of their home range, only data recorded after they had returned was used in the analysis.

\section{Home range analysis}

Home ranges were calculated from GPS locations recorded approximately every 24 hours. Only cheetahs with over 30 GPS locations (one per 
$24 \mathrm{~h}$ ) were included in the home range analysis. Animals were monitored for as long as possible and home ranges were tested for site fidelity using the animal movement extension program (Hooge et al. 1999a) and for accuracy using incremental area analysis using the Ranges 6 V1.2214 program (Kenward et al. 2003), in accordance with the recommendations by Hooge et al. (1999b). A home range size was deemed accurate if when calculated by the $95 \%$ peeled Minimum Convex Polygon (MCP) method, it reached an asymptote despite additional GPS locations.

The home range analyses were done using the animal movement extension program in conjunction with ArcView GIS 3.2 (Environmental Systems Research Institute Inc. 1992-2000). An individual's home range was calculated using the $95 \%$ peeled MCP (Jenrich \& Turner 1969) and the 95\% fixed kernel method using the least squares cross-validation (LSCV) smoothing factor. The core home range was calculated with the 50\% MCP and 50\% fixed kernel method. The MCP area and shape is known to be heavily influenced by outlying fixes, and may include large unused areas causing an overestimation of home range size (Harris et al. 1990). Despite its limitations the MCP was the method of choice in the past and was recommended by IUCN in 1994 (Burgman \& Fox 2003), as such this method was chosen to draw comparisons with previous studies. Home ranges calculated from utilization distributions such as the fixed kernel method, are considered more accurate than MCPs (Worton 1989; Worton 1995; Seaman \& Powell 1996; Seaman et al. 1999) therefore were used in the majority of the analyses.

\section{Sample intensity and sample effort}

To determine how frequently data points should be recorded to obtain an accurate home range size and daily movements, sub-sampling was done. Only cell/GPS collared cheetahs with more than one month of study were included in the analysis, i.e. F5, M4, M5 and M6. Data were sub-sampled to simulate GPS locations being collected multiple times a day (2 or 4 times a day), once a day, twice a week, once a week, once every two weeks and once a month. The 95\% and $50 \%$ fixed kernel methods were used to calculate new home range sizes for each data set, and daily movement was calculated as stated below.

The required sample effort, defined as the number of GPS locations required for a home range to be deemed accurate, was calculated using incremental area analysis using the Ranges 6 V1.2214 program (Kenward et al. 2003). Home range size was determined using the $95 \%$ MCP method for 3 , $4,5 \ldots n$ GPS locations, until all the GPS locations were included. A scatter graph was plotted and the point at which an asymptote was reached was determined.

\section{Movement}

Using daily GPS readings the mean, minimum and maximum daily movement of cheetahs were calculated using the animal movement extension program (Hooge et al. 1999a). If the interval between GPS locations was more than 24 hours, the distance travelled was calculated by dividing the total distance by the number of days of travel. If data were absent for more than three days, the distance was felt to be inaccurate and omitted. Cheetah are known to occasionally move atypically long distances per day, to avoid biasing the mean with these journeys, outliers of two standard deviations were not included in the calculation of mean movement per day. M3, M4, M5, M6, F5 and F1 were included in the movement data, including a breakdown of F5 before the birth of her cubs, in the den and as the cubs matured.

Mean, minimum and maximum movement between 02:00-08:00, 08:00-14:00, 14:00-20:00 and 20:00-02:00 were calculated for M4 and M5. The distance travelled for F5 was calculated between 01:00 and 13:00 for five months then between 03:00 and 15:00 for the following two months. Means are given \pm standard error.

\section{RESULTS}

\section{Study animals}

Of the 11 cheetahs collared only five had more than 30 recorded GPS points and were used in the home range analysis. The remaining cheetah were killed, or disappeared presumably due to collar failure, possible relocation out of range or death. Of all collared cheetah $55 \%$ were known to be shot by humans (Table 1).

\section{Home range sizes}

Variation in home range size calculated by the MCP and the fixed kernel method was detected. Unless otherwise stated all results relate to the fixed kernel method.

The mean female home range was $273.65 \pm$ $32.44 \mathrm{~km}^{2}(n=2)$ and the mean male home range 
Table 1. Details of cheetahs collared between 2003 and 2007. The cheetahs used in the home range analysis are shown in bold.

\begin{tabular}{|c|c|c|c|c|c|c|c|}
\hline ID & $\begin{array}{l}\text { Grouping at } \\
\text { time of capture }\end{array}$ & Age (y) & Collar type & $\begin{array}{l}\text { Botswana } \\
\text { district }\end{array}$ & $\begin{array}{l}\text { No. of days } \\
\text { in study }\end{array}$ & $\begin{array}{l}\text { No. of GPS } \\
\text { points }\end{array}$ & Outcome \\
\hline F1 & Female + cubs & 5 (cubs 0.3) & Radio & Southern & 681 & 98 & Battery died \\
\hline $\mathrm{F} 2$ & 3 adult females & 4 & Radio & Southern & 1 & 1 & Unknown \\
\hline F3 & Female + cubs & 6-8 (cubs 1) & Radio & Southern & 12 & 4 & Killed \\
\hline $\mathrm{F} 4$ & Female + cubs & 4 (cubs 1) & Radio & Southern & 77 & 11 & Unknown \\
\hline F5 & Lone female & 4 & Cell/GPS & Southern & 553 & 480 & $\begin{array}{l}\text { Collar } \\
\text { removed }\end{array}$ \\
\hline M1 & 2 males & $2-3$ & Radio & Southern & 1 & 1 & Unknown \\
\hline M2 & 3 males & 4 & Radio & Southern & 34 & 13 & Killed \\
\hline M3 & Single male & $5-6$ & Cell/GPS & Ghanzi & 23 & 17 & Killed \\
\hline M4 & Single male & 9 & Cell/GPS & Ghanzi & 45 & 41 & Killed \\
\hline M5 & Single male & 3 & Cell/GPS & Ghanzi & 141 & 137 & Killed \\
\hline M6 & 2 males & $3-4$ & Cell/GPS & Ghanzi & 59 & 39 & Killed \\
\hline
\end{tabular}

was $668.68 \pm 102.31 \mathrm{~km}^{2}(n=3)$. This sex difference was also seen in core range size; mean female core range was $27.83 \pm 17.51 \mathrm{~km}^{2}$ and mean male core range was $70.48 \pm 4.55 \mathrm{~km}^{2}$ (Table 2 ).

The mean female core range as a percentage of the home range was heavily effected by the period in the den, if this period was removed from the female data, the mean core range as a percentage of the home range was $25 \%$; much higher than that found in males (Table 2). A larger home range was observed in the coalition of two males M6, than in the lone males (Table 2).

\section{Female with cubs}

During the second month of monitoring F5 travelled $12.5 \mathrm{~km}$ in five hours between 19:00 and 00:00. She remained in this area, c. $10-18 \mathrm{~km}$ outside of her normal home range, for 10 days, in the following 17 months she never returned to this area. She had five cubs about three months later.

Whilst the cubs were in the den F5 occupied a much smaller range and travelled shorter distances per day than when the cubs had left the den. However, mean daily movements per day remained higher for the lone female, than when accompanied by cubs older than two months (Table 2).

\section{Home range overlap}

F5 occupied the Jwaneng research area concurrently with an uncollared female (F6, identifiable from spoor) from October 2005 to April 2007 (Fig. 1). They both used the entire area of the game reserve, and neighbouring farms. F6 left her first litter in July 2006 and returned with a second litter in November 2006, where she continued to overlap home ranges with $\mathrm{F} 5$, and at least one of the female subadults from the first litter (identified from a distinctive hind foot shape).

During December 2006 M4 and M5 shared an area of c. $119 \mathrm{~km}^{2}$ (based on an overlap of $100 \%$ MCPs, Fig. 2). However during this time M4, the older male, moved east and his signal was eventually lost. He may have been displaced by the younger male M5. M5 only remained in this area for an additional two months before moving north, he too may have been displaced by two males known to be in the area.

\section{Sampling intensity and effort}

Only minimal changes in home range size were detected when GPS locations were collected once or twice a week compared to the standardized once a day. However, when GPS locations were only recorded once every two weeks a large change in home range and core range size and location was observed (Table 3, Fig. 3).

Sampling intensity was also shown to affect the accuracy of mean and maximum daily movements. The mean and maximum number of $\mathrm{km}$ travelled per day increased when GPS readings were obtained more frequently (Table 3 ).

A home range was considered accurate when the $95 \% \mathrm{MCP}$ home range size reached an asymptote, i.e. further increases in the number of GPS locations did not alter the range size. The number of GPS locations may be considered the sample effort. Not all cheetah reached an asymptote, in those that did this occurred between 30 to 100 GPS locations, over a time period ranging from one month to 3.5 months in cell/GPS collared 
cheetah and nine months in a radiocollared female.

\section{Movement}

All cheetah had minimum movements of $0.00-1.51 \mathrm{~km} /$ day, therefore it is not unusual for cheetah to remain in the same location for over 24 hours (Table 2). Mean and maximum daily movement of males were larger than that of females (Table 2). Male cheetah moved further during the early morning hours (02:00-08:00) and less during the hottest part of the day (08:00-14:00). They moved equal distances during the afternoon (14:0020:00) and night hours (20:00-02:00), with the majority of long journeys taking place between 20:00 and 08:00 (Table 4). Females were observed to move more between the hours of $13: 00$ and 01:00 $(15: 00-03: 00)$ than between $01: 00$ and 13:00 (03:00-15:00) (Table 4).

\section{Season}

There were limited data to compare seasonal differences in cheetah home range size and movement. The home range and core range size of $\mathrm{F} 5$ was larger during the dry season, yet mean daily movement was highest during the wet season (Table 5).

\section{Previous studies}

Home range size for both male and female cheetah were larger than detected in previous studies, with the exception of coalition males and females in the Serengeti and all cheetah on Namibian farmland (Table 6).

\section{DISCUSSION}

\section{Home range and core range size}

The home range sizes (273.65 \pm $32.44 \mathrm{~km}^{2}$ for females and $668.68 \pm$ $102.31 \mathrm{~km}^{2}$ for males) of Botswana cheetah were larger than reported in protected areas in previous studies (Mills 1998; Purchase \& du Toit 2000; Broomhall et al. 2003; Cristescu 2006; Bissett \& Bernard 2007), with the exception of the Serengeti where female cheetah had a home range of $833 \mathrm{~km}^{2}$ and coalition cheetah had a range of $777 \mathrm{~km}^{2}$ (Caro 1994). Large home 


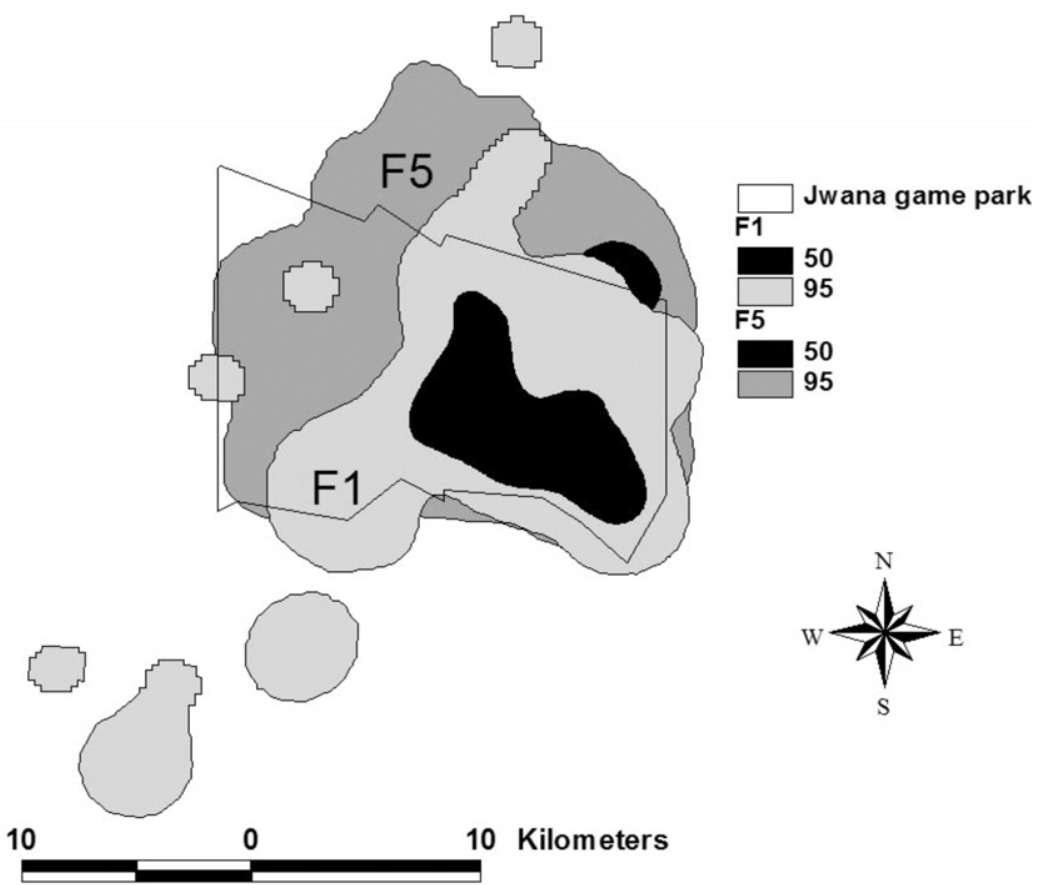

Fig. 1. The fixed kernel home range of F1 and F5 in Jwana game reserve.

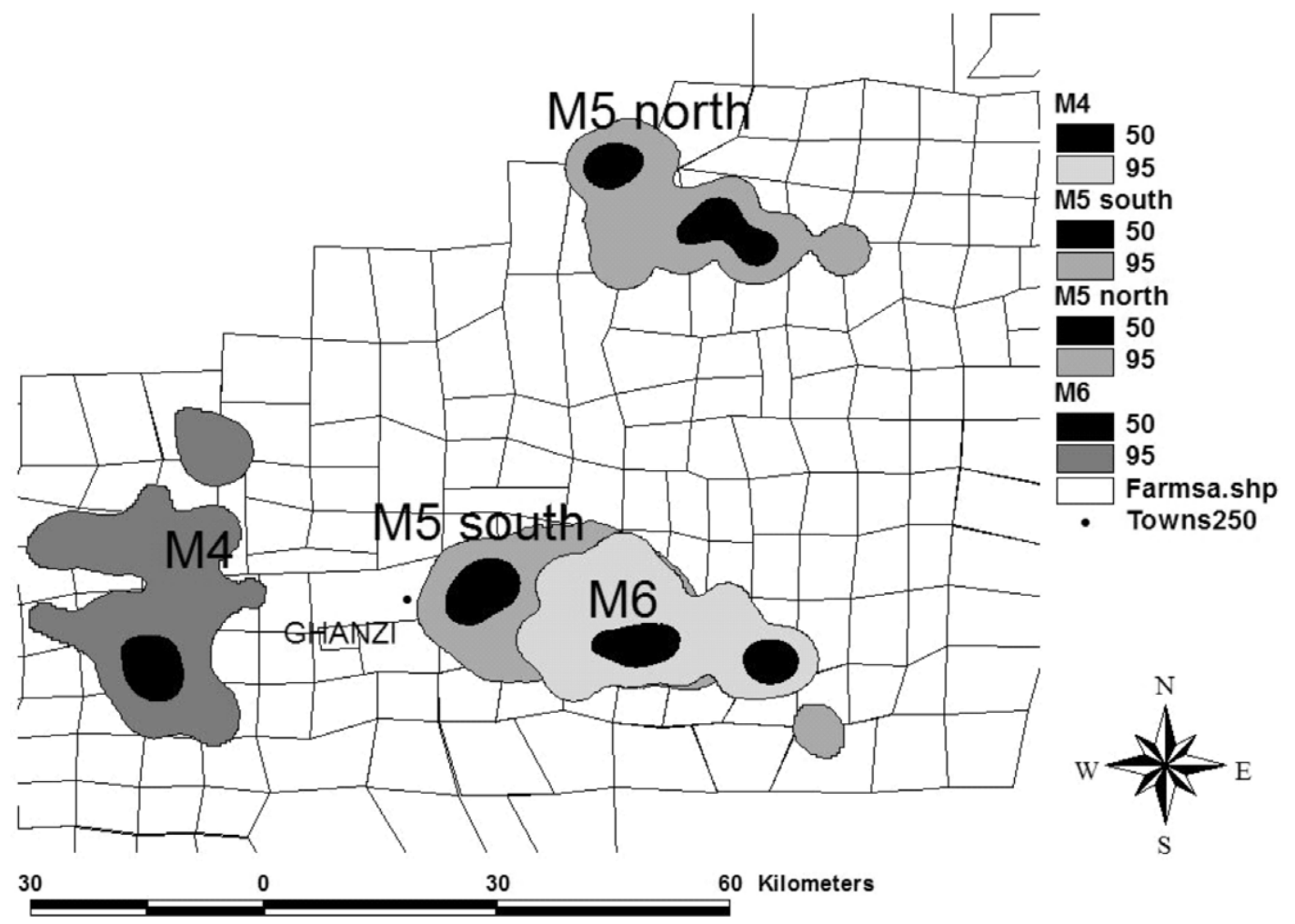

Fig. 2. The fixed kernel home range of M4, M5 and M6, on Ghanzi farmland. 
Table 3. The effect of sample intensity on home range (HR) and core range (CR) size and distance travelled per day. Data were sub-sampled to produce data sets with different time intervals between GPS locations.

\begin{tabular}{|c|c|c|c|c|c|c|c|c|}
\hline \multirow[b]{2}{*}{$\begin{array}{l}\text { ID \& GPS } \\
\text { point interval }\end{array}$} & \multicolumn{4}{|c|}{ Home range size $\left(\mathrm{km}^{2}\right)$} & \multicolumn{4}{|c|}{ Distance travelled (km/day) } \\
\hline & $n^{1}$ & $95 \%$ kernel & $50 \%$ kernel & $\begin{array}{l}\text { CR as } \\
\% \text { of } \mathrm{HR}\end{array}$ & $n^{2}$ & Mean \pm SE & Min & Max \\
\hline F5 (4×, 2x, 1×/day $)$ & 801 & 309.41 & 9.92 & 3.21 & 452 & $2.30 \pm 0.07$ & 0.00 & 17.23 \\
\hline F5 (1×/day) & 480 & 306.08 & 10.32 & 3.37 & 454 & $2.11 \pm 0.07$ & 0.00 & 13.85 \\
\hline F5 (2x/week) & 157 & 298.55 & 12.31 & 4.12 & 151 & $1.17 \pm 0.07$ & 0.00 & 7.79 \\
\hline F5 (1×/week) & 81 & 304.17 & 23.93 & 7.87 & 80 & $0.82 \pm 0.07$ & 0.00 & 3.08 \\
\hline F5 (1×/2 weeks) & 38 & 307.86 & 69.54 & 22.59 & 36 & $0.39 \pm 0.04$ & 0.01 & 0.87 \\
\hline F5 (1×/month) & 19 & 311.81 & 69.45 & 22.27 & 18 & $0.18 \pm 0.03$ & 0.01 & 0.35 \\
\hline M4 (4×/day) & 122 & 388.30 & 41.22 & 10.62 & 39 & $9.17 \pm 1.13$ & 0.04 & 25.06 \\
\hline M4 (1×/day) & 41 & 494.26 & 73.19 & 14.81 & 38 & $7.91 \pm 0.91$ & 0.33 & 21.99 \\
\hline M4 (2×/week) & 14 & 545.69 & 59.11 & 10.83 & 12 & $3.32 \pm 0.58$ & 0.45 & 9.84 \\
\hline M4 (1× week) & 7 & 491.64 & 63.03 & 12.82 & 6 & $1.47 \pm 0.56$ & 0.56 & 2.05 \\
\hline M4 (1×/2 weeks) & 4 & 723.00 & 189.99 & 26.28 & 3 & $0.92 \pm 0.30$ & 0.48 & 1.50 \\
\hline M5 (4×/day) & 255 & 566.45 & 76.82 & 13.56 & 132 & $8.12 \pm 0.46$ & 0.01 & 32.95 \\
\hline M5 (1×/day) & 84 & 663.24 & 76.66 & 11.56 & 130 & $6.06 \pm 0.39$ & 0.00 & 39.43 \\
\hline M5 (2×/week) & 26 & 735.07 & 110.86 & 15.08 & 39 & $3.41 \pm 0.39$ & 0.52 & 13.14 \\
\hline M5 (1×/week) & 13 & 742.22 & 97.20 & 13.10 & 18 & $1.84 \pm 0.29$ & 0.43 & 7.39 \\
\hline M5 (1×/2 weeks) & 6 & 831.71 & 244.36 & 29.38 & 3 & $1.79 \pm 0.45$ & 0.10 & 3.91 \\
\hline M6 (2x, 4x/day) & 59 & 660.49 & 50.51 & 7.65 & 36 & $6.49 \pm 0.74$ & 0.13 & 33.69 \\
\hline M6 (1×/day) & 39 & 848.55 & 61.60 & 7.26 & 32 & $5.06 \pm 0.62$ & 0.00 & 18.53 \\
\hline M6 (2×/week) & 15 & 987.83 & 124.71 & 12.62 & 13 & $4.20 \pm 0.80$ & 0.22 & 8.46 \\
\hline M6 (1×/week) & 8 & 819.85 & 273.32 & 33.34 & 6 & $1.32 \pm 0.26$ & 0.87 & 3.20 \\
\hline M6 (1× 2/weeks) & 4 & 443.17 & 108.47 & 24.48 & 3 & $0.93 \pm 0.26$ & 0.51 & 1.41 \\
\hline
\end{tabular}

${ }^{1} n=$ number of GPS points

${ }^{2} n=$ number of daily distances recorded.

ranges were also reported on Namibian farmlands, averaging $1651 \mathrm{~km}^{2}$ (Marker et al. 2007). The reason for these large ranges was unclear; in the Serengeti the migratory patterns of prey is thought to affect cheetah home range. On Namibian or Botswana farmland, the permanent water points encourage sedentary, but often patchy prey distributions, with high prey densities on game farms but lower densities on those cattle farms which experience poaching. This patchy prey distribution may be increasing cheetah home range size on Botswana farmland. Additionally, human conflict and perturbation may affect cheetah behaviour causing them to move further and occupy

Table 4. The mean, minimum and maximum distance travelled within each time frame for males and females.

\begin{tabular}{lrrrr}
\hline & \multicolumn{4}{c}{ Distance $(\mathrm{km})$} \\
\cline { 2 - 5 } Time & $n^{1}$ & Mean \pm S.E. & Min & Max \\
\hline Males $^{2}$ & & & & \\
02:00-08:00 & 165 & $3.46 \pm 0.26$ & 0.00 & 16.18 \\
08:00-14:00 & 164 & $1.14 \pm 0.12$ & 0.00 & 7.84 \\
14:00-20:00 & 163 & $2.16 \pm 0.15$ & 0.00 & 8.46 \\
20:00-02:00 & 163 & $2.44 \pm 0.22$ & 0.00 & 14.47 \\
Females & & & & \\
01:00-13:00 (03:00-15:00) & 205 & $0.88 \pm 0.08$ & 0.00 & 7.56 \\
13:00-01:00 (15:00-03:00) & 204 & $1.24 \pm 0.08$ & 0.00 & 6.36 \\
\hline
\end{tabular}

\footnotetext{
${ }^{1} n=$ number of daily distances recorded.

${ }^{2}$ Data from two males, M4 and M5.

${ }^{3}$ Data from one female, F5.
} 

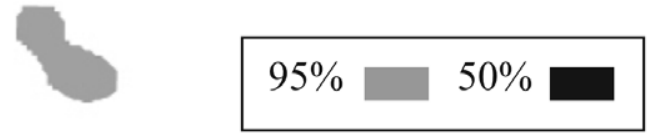

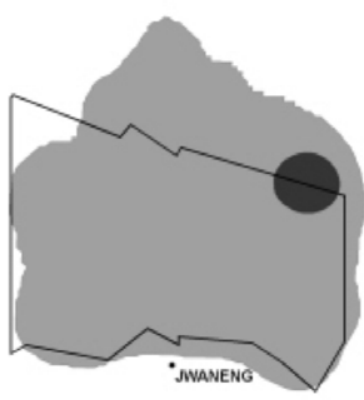

Multiple times a day

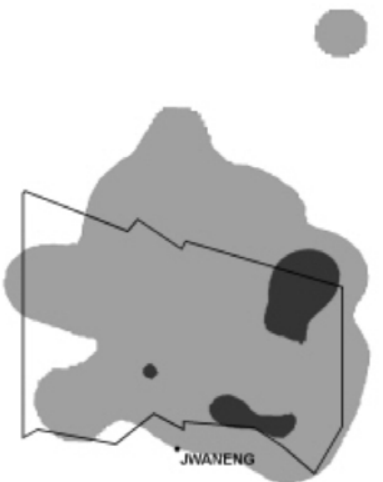

Once a week

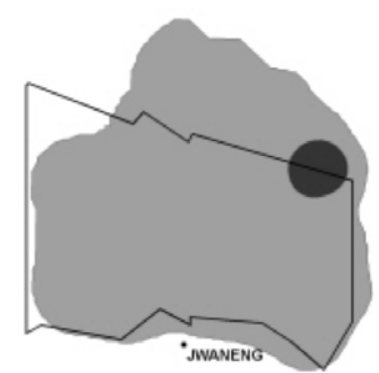

Once a day

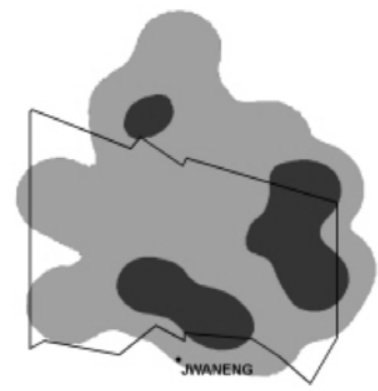

Once every two weeks

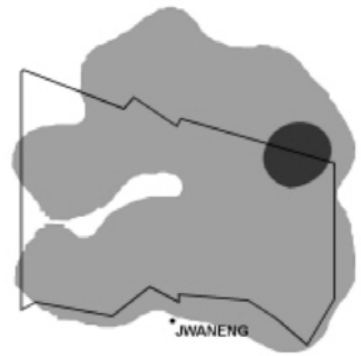

Twice a week

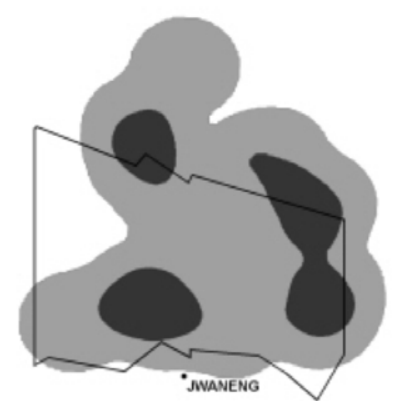

Once a month

Fig. 3. Changes in fixed kernel home range (95\%) and core range (50\%) size in F5 in Jwana game reserve, when the intervals between GPS locations were altered.

larger home ranges (Marker et al. 2007). The disturbance of social groupings, when a coalition member is shot, may alter the remaining cheetah's movements, while any encounter with humans may cause the cheetahs to move away, increasing its overall home range. This may partially account for the larger home ranges recorded in males than in females, as males were predominantly on farmland and females in protected areas. Female home range size was consistently smaller than male home range size by $200-600 \mathrm{~km}^{2}$, and showed less variation in size than was found between the male cheetahs. These differences may be due to sex, with males having to travel further in order to find females for breeding purposes (Caro 1994), or alternatively, they may be due to the location and outside stressors in the different areas of Ghanzi versus Jwaneng. In Ghanzi, farmers captured the study males at marking trees; no females were captured. In Jwaneng, male and female cheetahs were collared; however, the males were killed before enough data could be collected. Ghanzi cheetah may have suffered increased competition with leopard and occasionally lion compared to Jwaneng where lion were nonexistent and leopard numbers were very low. Farmer conflict, primarily with game farmers in Ghanzi, was more prevalent in this area than in Jwaneng, where the females primarily stayed within the game reserve (i.e. protected) and encountered less conflict with communal livestock farmers using predator avoidance techniques. Cheetahs may need to move more frequently on farmland due to these conflict issues, as they may 
Table 5. Home range size and distance travelled per day in the wet (October-March) and dry (April-September) season.

\begin{tabular}{|c|c|c|c|c|c|c|c|c|}
\hline \multirow[b]{2}{*}{ ID and season } & \multicolumn{4}{|c|}{ Home range size $\left(\mathrm{km}^{2}\right)$} & \multicolumn{4}{|c|}{ Distance travelled (km/day) } \\
\hline & $\overline{n^{1}}$ & $95 \%$ kernel & $50 \%$ kernel & $\begin{array}{l}\text { Core range } \\
\text { as } \% \text { of } \mathrm{HR}\end{array}$ & $n^{2}$ & Mean \pm SE & Min & $\operatorname{Max}$ \\
\hline F5 wet & 164 & 125.03 & 12.06 & 9.65 & 155 & $2.23 \pm 0.13$ & 0.00 & 13.85 \\
\hline F5 dry & 170 & 291.68 & 42.51 & 14.57 & 163 & $1.79 \pm 0.10$ & 0.03 & 7.63 \\
\hline F5 wet 2 & 126 & 198.35 & 42.12 & 21.24 & 114 & $2.20 \pm 0.13$ & 0.01 & 8.16 \\
\hline
\end{tabular}

${ }^{1} n=$ number of GPS points.

${ }^{2} n=$ number of daily distances recorded.

affect the availability of prey and the location of breeding females, therefore adding considerably to the stressors affecting cheetah movement on farms (Marker 2003b).

The single males (M4 and M5) held smaller home ranges than the coalition of two male cheetahs (M6). Previous work (Caro 1994) has failed to find this relationship, but sample size is too low to make any conclusions.

The increase in core range size of females after the den period may be due to the increased movements of the female and cubs in order to improve their chances of survival by finding more food to feed the cubs and/or to protect them from being located by other predators (Caro 1994; Durant 2000). Females have been shown to hunt larger prey during cub maturation (Caro 1994), which was noticed in this study with the regular taking of adult hartebeest.

\section{Movement}

The daily movement of the lone female (F5) decreased significantly when accompanied by cubs. Conversely, in the Serengeti, Caro (1994) observed that lone females spent less time moving than females with cubs. This observed difference may be due to $\mathrm{F} 5$ leaving her home range $(10-18 \mathrm{~km})$ to possibly find a suitable male (she gave birth to five cubs about three months later). Caro (1994) observed that females will occasionally travel large distances from 5-12 km a day for unknown reasons, although in these cases he felt

Table 6. Comparison of cheetah home range size. Sample size (number of cheetah) is shown in brackets.

\begin{tabular}{|c|c|c|c|c|c|c|}
\hline \multirow[t]{2}{*}{ Study } & \multirow[t]{2}{*}{ Location } & \multirow{2}{*}{$\begin{array}{l}\text { Protected } \\
\text { area }\end{array}$} & \multirow[t]{2}{*}{ Method } & \multicolumn{3}{|c|}{ Home range size $\left(\mathrm{km}^{2}\right)$} \\
\hline & & & & Single male & Coalition male & Female \\
\hline Caro (1994) & Serengeti Plains & $\mathrm{Y}$ & $\begin{array}{l}\text { Minimum } \\
\text { polygon }\end{array}$ & $37(22)$ & $777(9)$ & $833(19)$ \\
\hline Mills (1998) & Kalahari Gemsbok N.P. & $\mathrm{Y}$ & MCP & - & $125(3)$ & $320(4)$ \\
\hline $\begin{array}{l}\text { Purchase \& } \\
\text { du Toit (2000) }\end{array}$ & Matusadona, Zimbabwe & $\mathrm{Y}$ & $95 \% \mathrm{MCP}$ & $32.1(2)$ & - & $23.0(1)$ \\
\hline $\begin{array}{l}\text { Broomhall, Mills \& } \\
\text { du Toit (2003) }\end{array}$ & Kruger N.P & $\mathrm{Y}$ & $95 \% \mathrm{MCP}$ & $126(1)$ & $195(1)$ & $161(2)$ \\
\hline $\begin{array}{l}\text { Bissett \& Bernard } \\
(2006)\end{array}$ & Kwande S.Africa & $\mathrm{Y}$ & 95\% Kernel & - & $32.7(1)$ & $64.0(1)$ \\
\hline Cristescu (2006) & Shamwari. S.Africa & $\mathrm{Y}$ & $95 \%$ Kernel & - & & $61(2)$ \\
\hline $\begin{array}{l}\text { Marnewick \& } \\
\text { Cilliers (2006) }\end{array}$ & S.African farmland & $\mathrm{N}$ & $100 \% \mathrm{MCP}$ & - & $250(2)$ & - \\
\hline $\begin{array}{l}\text { Marker et al. } \\
(2007)\end{array}$ & Namibian farmland & $\mathrm{N}$ & $95 \%$ Kernel & $1490(15)$ & $1344(11)$ & $2161(15)$ \\
\hline This study & Botswana farmland & $\mathrm{N}$ & $95 \% \mathrm{MCP}$ & $316(2)$ & $598(1)$ & $409.9(2)$ \\
\hline This study & Botswana farmland & $\mathrm{N}$ & $95 \%$ Kernel & $579(2)$ & $849(1)$ & $668.7(2)$ \\
\hline
\end{tabular}


it was unlikely they were looking for a mate. This long distance travel was also noted with $\mathrm{F} 1$, who after leaving her first litter of cubs moved $14 \mathrm{~km}$ southwest of the reserve, returning four months later with a second litter. This repeated behaviour may indicate the lack of suitable males in the area for breeding, possibly due to human persecution. Alternatively, the females may be searching for numerous males to breed with in order to increase genetic variability, thereby possibly increasing cub survival (Gottelli et al. 2007).

The maximum and mean daily movement was larger in males than females, an observation also made in Namibian cheetahs (Marker 2002). This difference may be explained by their need to defend their territory in order to obtain females, or the males may have travelled further to occupy territory vacancies or been forced to move to avoid human conflict or competition with other cheetahs or predators. Often single males are pushed out of an area by coalitions or other territorial single males, forcing them to take on a more wandering form of life style (Durant et al.2004). This may have been the case with M5 who occupied a home range of $663 \mathrm{~km}^{2}$ for 87 days, then travelled $40 \mathrm{~km}$ north to set up a $422 \mathrm{~km}^{2}$ range. M5 only returned to his southern home range for three days before moving back to the northern area. This may have been due to the movement of a known coalition of two males into M5's southern range.

Males were shown to travel larger distances in the late evening and early morning (20:00-08:00) than during the day. All long distance $(>8.5 \mathrm{~km})$ travel occurred during the study period of November-April when there was approximately four hours of daylight during those timeframes. Therefore it may be assumed that a large proportion of this movement was in the dark. Cheetah are generally believed to be diurnal, however increasing evidence is showing that male cheetah frequently move/hunt at night even in areas with a high lion presence (Bissett \& Bernard 2007). Females moved larger distances from 13:00-01:00, than from 01:00-13:00. A more detailed analysis with shorter time periods would be required to speculate about their movements, and their preference for daylight or darkness for travelling or hunting, and the affect cub presence has on that decision.

\section{Season}

The female home range size in the dry season was slightly larger than during the wet season.
This may be due to the increased movement of prey during the dry season for food and water requirements, along with vegetation changes that may affect cheetah cover and hunting capabilities. There was not enough data to compare male seasonal movement changes.

\section{Sampling intensity}

An accurate home range size is essential for cheetah management decisions. The selected interval in GPS readings could result in inaccurate estimates of home range size (Rooney et al. 1998), which could be misleading as to the total area the cheetah population would need in order to be self sustaining. The selected interval also influences the location and size of the core range, which may place an emphasis on the wrong size of areas and location of habitat actually required for conservation. Although non-significant the biggest difference recorded was between readings obtained once a day and once every two weeks. Girard et al. (2006) also found that habitat selection could be accurately determined in Moose (Alces alces) when GPS locations were selected once every one, three, or seven days, but was inaccurate when recorded once every 14 days.

Ideally, readings should be obtained daily, however, in long-term studies where animals are likely to remain in the study area for a long period of time, it may be possible to obtain an accurate home range size at longer intervals between GPS locations. In this study, the F5 female had been followed eight times longer than the males. For the female it was possible to obtain an accurate home range size when readings were obtained twice a week, but in males anything less than every 24 hours became increasingly inaccurate.

Additionally, the accuracy of mean and maximum daily movement data was shown to decrease when GPS locations were recorded less than once a day. Reynolds \& Laundre (1990) and de Solla et al. (1999) concluded that increasing the time interval between observations under-estimates the true distance travelled. If a study intends to closely examine movement data, readings of at least once per day should be recorded. The importance of time interval must be understood when designing a monitoring program, in conjunction with the financial considerations of point collection using cell/GPS collar downloads versus VHF monitoring. GPS locations are frequently accurate within $7 \mathrm{~m}$ for some collars; however the possibility of problems with satellite alignment frequently causes loss of 
data. Therefore, setting the GPS collars to download at least twice a day increases the chances of collecting enough positional data to get reliable results for interpretation. It would be less expensive and time consuming than daily VHF monitoring.

A limitation of this study was the low number of collared animals in conjunction with the length of time the collared cheetahs were studied. Collar malfunction and dispersal of cheetah out of monitoring range (Durant et al. 2004) had a negligible effect, however cheetah-farmer conflict resulted in at least $55 \%$ of losses (some of the cheetah lost to unknown factors were most likely killed). These killings were not due to actual livestock loss, but appear to be due to the perceived threat of loss and an overall intolerance to predators, this problem was also recorded in Namibian farmlands (Marker et al. 2003b).

This is the first study in Botswana specifically examining cheetah home range size and movements. A trend in female and male range size and distance travelled was observed, but more work needs to be done to establish the influence of sex, human persecution and intraguild competition. Studies in protected areas such as the CKGR and WMAs of Botswana are needed to establish the differences between cheetah movements in protected areas versus unprotected areas such as farmlands.

The understanding of cheetah movement between the sexes and during cub rearing is important for the development of management strategies that will protect suitable habitats for these populations to survive. By continuing to study and understand these needs, the management of populations will be more self sustaining, through the maintenance of farmland and protected areas. The large reported home ranges of males in this study $\left(668 \mathrm{~km}^{2}\right.$ encompassing 11 farms (roughly $60 \mathrm{~km}^{2}$ each)) means that exposure to just one intolerant farmer in the area may be a threat to the individuals survival, and may have far reaching effects altering social patterns and ranging behaviour over a large area. Large home ranges may cause cheetah population estimates to be inflated due to repeated sightings throughout one cats home range (Marker et al. 2007). This may add to the communities' intolerance of cheetah. As highlighted in this study, the greatest difficulty was in obtaining sufficient data from the study animals before they disappeared or were killed. This signifies the plight of the cheetah farmer conflict in these areas, and the need for continued community education and research on the effectiveness of predator management strategies and their implementation.

\section{ACKNOWLEDGEMENTS}

This study was supported by Cheetah Conservation Botswana, especially Rebecca Klein and Dr Kyle Good without whom this research would not have been possible. We would like to thank Debswana for allowing our project to reside, gather data and monitor cheetah in Jwana Game Reserve. We also thank the Department of Wildlife and National Parks of Botswana for the permits to work with the cheetah and to Charleen Gavette for technical support with ArcView.

\section{REFERENCES}

BEKKER, R.P. \& DE WIT, P.V. 1991. Vegetation map of the Republic of Botswana. Soil Mapping and Advisory Services Project. Ministry of Agriculture, Gaborone.

BISSET, C. \& BERNARD, R.T.F. 2007. Habitat selection and feeding ecology of the cheetah (Acinonyx jubatus) in thicket vegetation: is the cheetah a savannah specialist? J. Zool. 271: 310-317.

BROOMHALL, L.S. 2001. Cheetah Acinonyx jubatus in the Kruger National Park: a comparison with other studies across the grassland-woodland gradient in African savannas. M.Sc. thesis, University of Pretoria, Pretoria.

BROOMHALL, L.S., MILLS, M.G.L. \& DU TOIT, J.T. 2003. Home range and habitat use by cheetahs (Acinonyx jubatus) in the Kruger National Park. J. Zool. 261: 119-128.

BURGMAN, M.A. \& FOX, J.C. 2003. Bias in species range estimates from minimum convex polygons: implications for conservation and options for improved planning. Anim. Conserv. 6: 19-28.

CARO, T. M. 1994. Cheetahs of the Serengeti Plains Group living in an asocial species. University of Chicago Press, Chicago.

CRISTESCU, B. 2006. Space use and diet of selected large carnivores in a large South African game reserve. M.Sc. thesis, University of Leeds.

DE SOLLA, S.R., BONDURIANSKY, R. \& BROOKS, R.J. 1999. Eliminating autocorrelation reduces biological relevance of home range estimates. J. Anim. Ecol. 68(2): 221-234.

DLUPU (District Land Use Planning Unit) 1995. Ghanzi District Land Use Zoning Plan. Land Use Planning Unit, Ghanzi, Namibia.

DURANT, S.M. 2000. Living with the enemy: avoidance of hyenas and lions by cheetahs in the Serengeti. Behav. Ecol. 11: 624-632.

DURANT, S.M. 2002. Identifying optimum habitat for threatened cheetahs: plains or woodlands? Conference presentation at Society for Conservation Biology 16th Annual Meeting, 14-19 July, 2002, Canterbury, U.K.

DURANT, S.M., KELLY, M. \& CARO, T.M. 2004. Factors affecting life and death in Serengeti cheetahs: environment, age, and sociality. Behav. Ecol. 15(1): 11-22. 
GIRARD, I., DUSSAULT, C., OUELLET, J.P., COURTOIS, R. \& CARON, A. 2006. Balancing number of locations with number of individuals in telemetry studies. J. Wildlife Manage. 70(5): 1249-1256.

GREENWAY, P. 2001. Botswana. 1st edn. Lonely Planet Publications, Australia.

GOTTELLI, D., WANG, J., BASHIR. \& DURANT, S.M. 2007. Genetic analysis reveals promiscuity among female cheetahs. Proc. Royal Soc. B. 274: 19932001.

GROS, P.M. \& REJMANEK, M. 1999. Status and habitat preferences of Uganda cheetahs: an attempt to predict carnivore occurrence based on vegetation structure. Biodivers. Conserv. 8: 1561-1583.

HARRIS, S., CRESSWELL, W.J., FORDE, P.G., TREWHELLA, W.J., WOOLLARD, T. \& WRAY, S. 1990. Home-range analysis using radio-tracking data - a review of problems and techniques particularly as applied to the study of mammals. Mammal Rev. 20: 97-123.

HOOGE, P.N., EICHENLAUB, W. \& SOLOMAN, E. 1999a. The animal movement program. USGS, Alaska Biological Sciences Centre, Anchorage.

HOOGE, P.N., EICHERLAUB, W. \& SOLOMAN, E. 1999b. Using GIS to analyze animal movements in the marine environment. Analyzing Animal Movements. Online at: http://www.absc.usgs.gov/glba/ gistools/

IUCN 2007. The IUCN Red List of Threatened Species. Online at: http://www.iucnredlist.org (downloaded 2 November 2007).

JENRICH, R.I. \& TURNER, F.B. 1969. Measurement of non-circular home range. J. Theor. Biol.22:227-237.

JWANENG METEOROLOGY DEPARTMENT, 2007. Jwaneng, Botswana.

KENWARD, R.E., SOUTH, A.B. \& WALLS, S.S. 2003. Ranges6 v1.2: For the analysis of tracking and location data. Online manual. Anatrack Ltd, Wareham, U.K. Online at: http://www.anatrack.com/

KLEIN, R. 2007. Status report for the cheetah in Botswana. Cat News, Special Issue 3: 14-21.

MARKER, L. 2002. Aspects of cheetah (Acinonyx jubatus) biology, ecology and conservation strategies on Namibian farmlands. Ph.D. thesis, University of Oxford, Oxford.

MARKER, L., KRAUS, D., BARNETT, D. \& HURLBUT, S. 2003a. Cheetah survival on Namibian farmlands. Cheetah Conservation Fund, Windhoek, Namibia.

MARKER, L.L., DICKMAN, A.J., MILLS, M.G.L. \& MACDONALD, D.W. 2003b. Aspects of the management of cheetahs, Acinonyx jubatus jubatus, trapped on Namibian farmlands. Biol. Conserv. 114: 401412.

MARKER, L.L., DICKMAN, A.J., MILLS, M.G.L., JEO, R.M. \& MACDONALD, D.W. 2007. Spatial ecology of cheetahs on north-central Namibian farmlands.
J. Zool. 274: 226-238.

MARNEWICK, K. \& CILLIERS, D. 2006. Range use of two coalitions of male cheetahs, Acinonyx jubatus in the Thabazimbi district of the Limpopo province, South Africa. S. Afr. J. Wildl. Res. 36(2): 147-151.

MILLS, M.G.L. 1998. Cheetah ecology and behaviour in East and South Africa. In: B.L. Penzhorn (Ed.), Symposium on cheetahs as game ranch animals (pp. 18-22). Onderstepoort, South Africa.

PURCHASE, G.K. \& DU TOIT, J.T. 2000. The use of space and prey by cheetahs in Matusadona National Park, Zimbabwe. S. Afr. J. Wildl. Res. 30(4): 139-144.

PURCHASE, G., MARKER, L., MARNEWICK, K., KLEIN, R. \& WILLIAMS, S. 2007. Regional assessment of the status, distribution and conservation needs of cheetah in Southern Africa. Cat News, Special Issue 3: 44-46

REYNOLDS, T.D. \& LAUNDRE, J.W. 1990, Time intervals for estimating pronghorn and coyote home ranges and daily movements. J. Wildlife Manage. 54: 316-322.

ROONEY, S.M., WOLFE, A. \& HAYDEN, T.J. 1998. Auto-correlated data in telemetry studies: time to independence and the problem of behavioral effects. Mammal Rev. 28(2): 89-98.

SEAMAN, D.E. \& POWELL, R.A. 1996. An evaluation of the accuracy of kernel density estimators for home range analysis. Ecology 77(7): 2075-2085.

SEAMAN, D.E., MILLSPAUGH, J.J., KERNOHAN, B.J., BRUNDIGE, G.C., RAEDEKE, K.J. \& GITZEN, R.A. 1999. Effects of sample size on kernel home range estimates. J. Wildlife Manage. 63(2): 739-747.

STANDER, P.E., HADEN, P.J., KAGAE \& GHAU 1997. The ecology of asociality in Namibian leopards. J. Zool. 242: 343-364.

THOMAS, D.S. 2002. Sand, grass and cattle: The modern Kalahari environment. In: D. Sporton \& D. Thomas (Ed.), Sustainable livelihoods in Kalahari environment: contributions to global debates (pp. 21-38). Oxford University Press, New York.

TUYTTENS, F.A.M. \& MACDONALD, D.W. 2000. Consequences of social perturbation for wildlife management and conservation. In: L.M. Gosling \& W.J. Sutherland (Ed.), Behaviour and conservation (pp. 315-329). Cambridge University Press, Cambridge.

WINTERBACH, C. 2001. Draft predator management strategy. Department of Wildlife and National Parks, Gaborone.

WORTON, B.J. 1989. Kernel methods for estimating the utilization distribution in home-range studies. Ecology 70(1): 164-168.

WORTON, B.J. 1995. Using Monte-Carlo simulation to evaluate kernel-based home-range estimators. J. Wildlife Manage. 59(4): 794-800.

Corresponding Editor: J.A.J. Nel 